\title{
An Overview of the Social-Economic Development of the Constituent Territories of the North Caucasus Federal District
}

\author{
Akbasheva A.A.* \\ Chair of Economic Analysis and Accounting \\ Moscow Financial and Industrial University \\ "Synergy" Karachayevo-Cherkesskiy Branch \\ Cherkessk, Russia \\ e-mail: Anzhela-Akbasheva@mail.ru
}

\section{Dzakhmisheva I.Sh.}

Chair of Commodity Science, Tourism and Law Kabardino-Balkarian State Agrarian University named after V.M. Kokov

Nalchik, Russia

e-mail irina_dz@list.ru

\author{
Shevkhuzheva L.A. \\ Chair of Economic Security \\ Moscow Financial and Industrial University \\ "Synergy" Karachayevo-Cherkesskiy Branch \\ Cherkessk, Russia \\ e-mail shevkhuzheval@mail.ru \\ Masalova J.V. \\ Chair of Economic Analysis and Accounting, \\ Moscow Financial and Industrial University \\ "Synergy" Karachayevo-Cherkesskiy Branch \\ Cherkessk, Russia \\ e-mail masalova.8080@mail.ru
}

improving regulatory and organizational support and improving mechanisms of state support.

Keywords - overview, population, social-economic development, management, agriculture.

\section{INTRODUCTION}

Qualitative changes are taking place in the socialeconomic development of regions in the modern economy, which served as the basis for enhancing differentiation and exacerbation of social contradictions between self-sufficient and poor regions. The existing differences determine the need to find optimal ways to solve problems by increasing socialeconomic development, creating infrastructure, developing the existing and forming a modern business sector in order to create new jobs, optimal enterprise management as a catalyst for recovery processes and economic development. According to scientists [1-16] the priority should be the formation and use of human capital, the adaptation of tools in the agricultural sector, the development of which will provide strong motivation for the business sector of the agro-industrial complex (AIC) to build their own potential and further development, and expansion in order to improve social and the economic situation of the population. Financial and other support to agricultural enterprises in crop production and animal husbandry should be considered as an auxiliary mechanism of their development policy [2,4-5]. We note that one of the management problems is the lack of a clear system for managing the reproduction process; therefore, the main task in the field of economic management is the integration of the available individual controls into an integrated system. The solution to this problem is seen in the study of the current social-economic status of the constituent territories of the North Caucasus Federal District, which determines the 
dominant resource opportunities and prospects for further economic development of the region.

The purpose of the research is to analyze the current social-economic status and substantiation of the main directions of economic development of the constituent territories of the North Caucasus Federal District.

\section{METHODS AND MATERIALS}

The initial information base was the data of statistical collections "Regions of Russia. Social-economic indicators. 2011-2019 years" The research methodological base was composed of traditional principles, structural-functional and systemic approaches. At the research stage, modern methods were used: statistical, systemic, abstract-logical, dialectic and others.

\section{RESULTS}

The agro-industrial complex of the North Caucasus Federal District (NCFD) has a powerful natural (land), demographic, economic and historical-cultural potential, which, if used more fully, rationally and efficiently, can ensure sustainable diversified development, full employment, a high level and decent quality of life population [2].

The Karachayevo-Cherkesskaya Republic (KChR) is one of 7 constituent territories of the NCFD, formed in 2010 by the decree of the President, and one of 10 constituent territories of the North Caucasus Economic Region. As part of the NCFD there is one region and six republics, occupying more than 170 thousand square meters kilometers with the central location of the plenipotentiary representative in the city of Pyatigorsk. The KChR is located on the 4th place in the territory area (14.3 thousand square kilometers) and on the 6th place in terms of the population (469.9 thousand people) of the NCFD (Fig. 01).

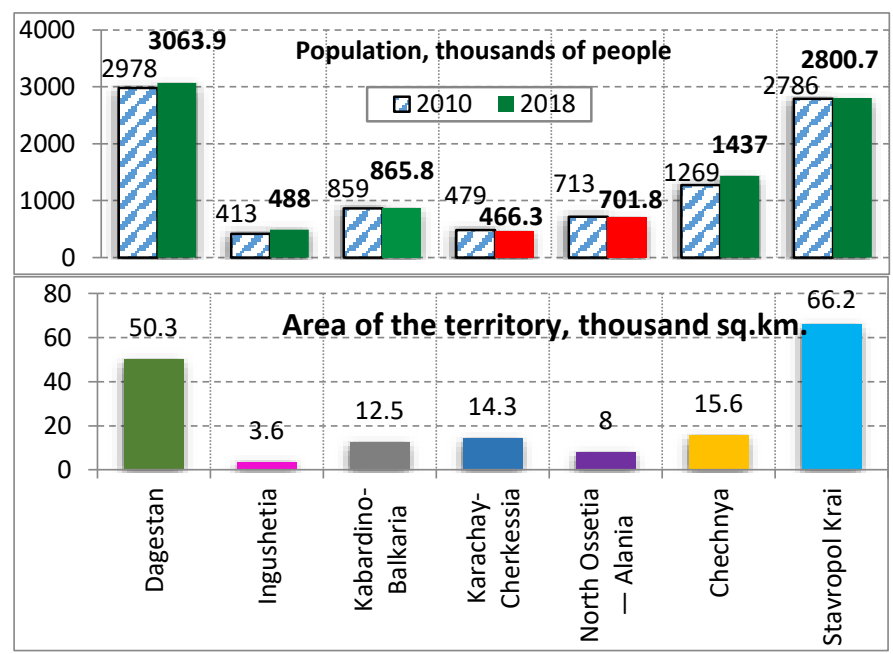

Fig. 1. The dynamics of the population and the area of the constituent territories of the North Caucasus Federal District at the beginning of the year.

The KChR is located on the northern side of the Caucasus Mountains and borders on the Stavropol and Krasnodar Territories and the Kabardino-Balkarian Republic. The KChR consists of 100 municipalities, including 10 municipal districts, 2 urban districts and 88 settlements (5 urban and 83 rural).

The population of the NCFD in 2018 amounted to 9,823.5 thousand people which corresponds to $6.7 \%$ of the population of the Russian Federation, which is 326.5 thousand people or $3.4 \%$ more than the same indicator in 2010 (9497 thousand people). The positive trends in population growth during this period were 4 entities: Dagestan ( +95 thousand people or $+3 \%$ ), Ingushetia (41 thousand people or $+10 \%)$, Chechnya (+96 thousand people or $+8 \%$ ) and Stavropol Territory (+17 thousand people or $+1 \%)$.

The number of inhabitants decreased in 2 entities: in the Karachayevo-Cherkesskaya Republic - by 12.7 thousand people $(-2.7 \%)$, in North Ossetia-Alania - by 11.2 thousand people $(-1.6 \%)$ (Fig. 01)

Among all 7 entities of the NCFD the KarachayevoCherkessaya Republic occupies a leading place in terms of the area per inhabitant (Fig. 02).

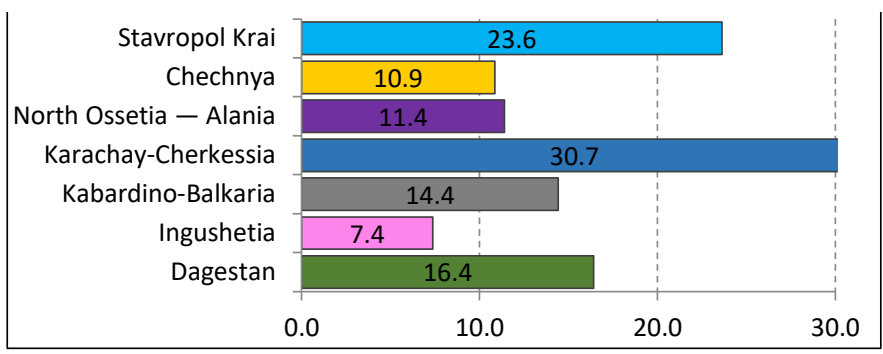

Fig. 2. Territory area per 1 thousand people of the subjects of the North Caucasus Federal District in 2020, sq. km

The population of the North Caucasus Federal District is unevenly distributed, with more than half of the population living in Dagestan and the Stavropol Territory (59.7 \%). In Karachayevo-Cherkessia and Ingushetia, a smaller share of the population in the structure of the North Caucasus Federal District lives (4.7\% and $5 \%$, respectively) (Fig. 03).

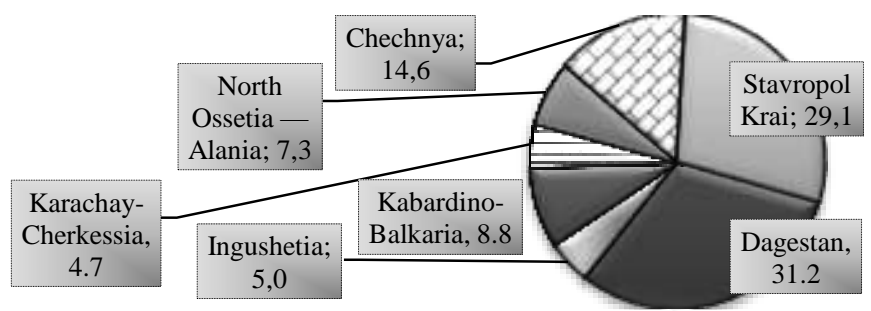

Fig. 3. He structure of the population of the North Caucasus Federal District in $2018, \%$

The population of the KChR in 2018 amounted to 466.4 thousand people. (474 thousand people in 2010) with a share of the urban population of $42.7 \%$ (44\% in 2010) and $57.3 \%$ of the rural population (56\% in 2010). In the Russian Federation (RF), the proportion of the urban population was $74.4 \%$, of the rural population $-25.6 \%$, with an upward trend in the urban population; in the NCFD - $49.8 \%$ and $50.2 \%$ respectively with a tendency to decrease in the share of the rural population. The urban population exceeds the number of rural settlements in 4 entities of the NCFD: in Ingushetia $(55.3 \%$ versus $44.7 \%)$, in the $\operatorname{KBR}(52.1 \%$ versus $47.9 \%)$, 
North Ossetia-Alania (64.2\% versus $35.8 \%$ ), in the Stavropol Territory (58.4\% versus $41.6 \%$ ). In 2010 most of the population of Ingushetia was rural, however, the situation has changed. Trends in urban population growth are observed in all entities of the NCFD. However, in 2018 the proportion of the rural population remains more than urban residents in Dagestan, the KChR and Chechnya [2].

An increase in the number of people under working age is observed in the R F (+18.6\%) and in the NCFD as a whole, despite their decline in Dagestan and Ingushetia. Moreover, their share is increasing both in the RF and in the NCFD and amounts to slightly more than the fifth part $(18.6 \%$ in the RF and $24.3 \%$ in the NCFD) of the total population, in the $\mathrm{KChR}$ - about the fifth part $(20.7 \%)$. The number of people of working age in the RF and the NCFD decreases annually so since 2010 the value of the indicator has decreased by 6 percentage points and amounted to $56 \%$, in the $\mathrm{R} \mathrm{F}$ the decrease was 3 percentage points and stood at $57.8 \%$. The decrease in the number of able-bodied people in the NCFD was affected by their decrease in all the constituent entities of the District.

From 2010 to 2018 the population over working age increased in the $\mathrm{KChR}$ by 4 percentage points to $22.1 \%$, in the NCFD - by 3 percentage points to $17.9 \%$, in the RF also by 3 percentage points to $25.4 \%$. At the same time if in the $\mathrm{RF}$ as a whole and in the NCFD an uneven increase in the value of this indicator is observed, then in the KChR the accelerating rate of its growth is detected.

The birth rate calculated as the number of births per 1000 people in 2010-2018 decreases in the whole of the RF, the NCFD and in all its entities. At the same time in terms of the birth rate indicator, the NCFD is in first place: for every 1000 people there are 15 births (in the KChR - 11; in Chechnya - 22), in the RF this indicator is much lower (11.5 births). NCFD is characterized by a drop in mortality, due to its reduction in all its constituent entities. In absolute terms in the NCFD mortality is 1.7 times lower than the average for the RF.

The highest level of life expectancy is observed in the North Caucasus Federal District (75.9 years), and the maximum level is in Ingushetia with a value of 81.6 years (men -78.6 years, women -84.1 years) which is higher than the average life expectancy in RF (72.7 years) for almost 9 years. The KChR takes the fourth place in life expectancy among the subjects of the Russian Federation (75.9 years: men -71.4 years, women -80 years).

In 2018 as in previous years the NCFD stands out among other federal districts with a negative migration growth due to a significant outflow of the population from 5 constituent entities (from North Ossetia - Alania, Dagestan, the KBR, Ingushetia and the $\mathrm{KChR}$ ). Note that the population mainly migrates to other regions of Russia. A significant proportion of migrants are represented by labor power.

In $201880.3 \%$ of the labor power was employed in the $\mathrm{KChR}$ economy, including those engaged in the production of products for sale or exchange of products in households, in the NCFD this share was $84.2 \%$, in the RF - $94.4 \%$. In the
Stavropol Territory, the maximum value of a similar indicator is observed $(91.3 \%)$, in Ingushetia, the minimum value is $71.5 \%$ (Fig. 04).

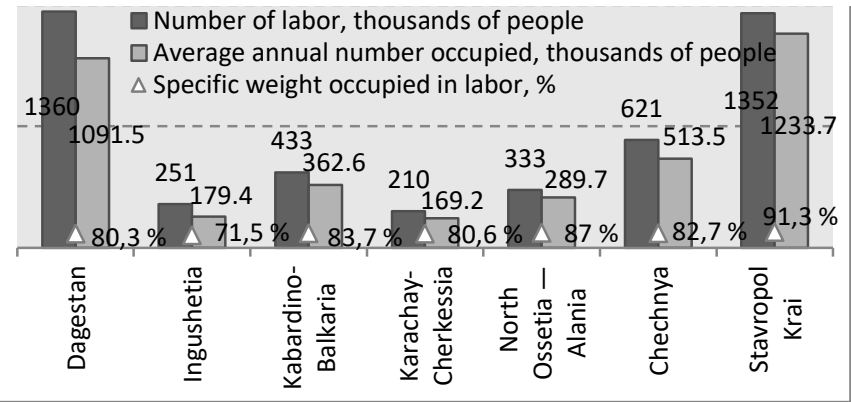

Fig. 4. Indicators of the labor force and the average annual number of employed population of the subjects of the North Caucasus Federal District in 2018

The largest part of the employed population $(18.4 \%)$ of the NCFD is engaged in agricultural production, hunting, forestry, fishing and fish farming (707.7 thousand people out of 3839.6 thousand people) (Table 01 ).

TABLE I. DYNAMICS OF THE NUMBER OF PEOPLE EMPLOYED IN AGRICULTURE, FORESTRY AND FISHERIES OF THE NORTH CAUCASUS FEDERAL DISTRICT, THOUSAND PEOPLE.

\begin{tabular}{|l|l|l|l|l|l|l|l|}
\hline \multirow{2}{*}{ Region } & \multicolumn{4}{c|}{ Years } & \multicolumn{2}{c|}{$\begin{array}{c}\text { Changes (+,-) } \\
\text { 2018 to 2010 }\end{array}$} & \multicolumn{2}{c|}{$\begin{array}{c}\text { Changes (+,-) } \\
\text { 2018 to 2014 }\end{array}$} \\
\cline { 2 - 8 } & $\mathbf{2 0 1 0}$ & $\mathbf{2 0 1 4}$ & $\mathbf{2 0 1 8}$ & Absolute & Relative & Absolute & Relative \\
\hline $\begin{array}{l}\text { Russian } \\
\text { Federation, } \\
\text { including: }\end{array}$ & 6879.4 & 6502.9 & 5074.5 & -376.5 & 94.5 & -1428.4 & 78.0 \\
\hline $\begin{array}{l}\text { North Caucasus } \\
\text { Federal District } \\
\text { including: }\end{array}$ & 654.4 & 720.3 & 707.7 & 65.9 & 110.1 & -12.6 & 98.3 \\
\hline $\begin{array}{l}\text { Stavropol } \\
\text { region }\end{array}$ & 213.2 & 219.3 & 197.8 & 6.1 & 102.9 & -21.5 & 90.2 \\
\hline Chechnya & 33.1 & 63.9 & 103.3 & 30.8 & 193.1 & 39.4 & 161.7 \\
\hline $\begin{array}{l}\text { North Ossetia } \\
\text { Alania }\end{array}$ & 45.5 & 45.2 & 31.4 & -0.3 & 99.3 & -13.8 & 69.5 \\
\hline $\begin{array}{l}\text { Karachay- } \\
\text { Cherkessia }\end{array}$ & 40.3 & 40.7 & 23.3 & 0.4 & 101.0 & -17.4 & 57.2 \\
\hline $\begin{array}{l}\text { Kabardino- } \\
\text { Balkaria }\end{array}$ & 67 & 66.8 & 70.3 & -0.2 & 99.7 & 3.5 & 105.2 \\
\hline Ingushetia & 7.4 & 6.8 & 27.2 & -0.6 & 91.9 & 20.4 & in $4 \mathrm{p}$. \\
\hline Dagestan & 247.9 & 277.7 & 254.5 & 29.8 & 112.0 & -23.2 & 91.6 \\
\hline
\end{tabular}

An overview of the population employed in agriculture in the NCFD in 2014-2018 allowed us to establish their negative dynamics, due to their decrease in the $\mathrm{KChR}$ - by $42.8 \%$, in the North Ossetia-A - by $30.5 \%$, in the Stavropol Territory by $9.8 \%$ and in Dagestan by $8.4 \%$. The number of agricultural workers in 2014-2018 decreased both in the whole of the RF and in the NCFD. In the KChR their number has almost halved. A favorable situation has developed in Ingushetia where the value of this indicator has increased 4 times.

At the same time in the period from 2010 to 2018 a positive growth rate of the number of agricultural workers $(+10.1 \%)$ is observed in the NCFD which is undoubtedly a positive fact. 
The unemployment rate in 2018 in the NCFD determined by the ratio of the number of unemployed to the workforce is twice that of the RF as a whole but a positive fact is its decrease in 2018 compared to 2010 by 5.5 percentage points. At the same time in KChR and RNO-A, an increase in the unemployment rate by 3.2 percentage points is observed and 2.1 percentage points respectively (Table 02 ).

TABLE II. DYNAMICS OF UNEMPLOYMENT IN THE SUBJECTS OF THE NORTH CAUCASUS FEDERAL DISTRICT

\begin{tabular}{|l|l|l|l|l|l|l|l|}
\hline \multicolumn{1}{|c|}{ Region } & $\begin{array}{l}\mathbf{2 0 1 0} \\
\text { year }\end{array}$ & $\begin{array}{l}\mathbf{2 0 1 4} \\
\text { year }\end{array}$ & $\begin{array}{l}\mathbf{2 0 1 5} \\
\text { year }\end{array}$ & $\begin{array}{l}\mathbf{2 0 1 6} \\
\text { year }\end{array}$ & $\begin{array}{l}\mathbf{2 0 1 7} \\
\text { year }\end{array}$ & $\begin{array}{l}\mathbf{2 0 1 8} \\
\text { year }\end{array}$ & $\begin{array}{l}\mathbf{2 0 1 8} \text { to } \\
\mathbf{2 0 1 0}\end{array}$ \\
\hline $\begin{array}{l}\text { Russian } \\
\text { Federation }\end{array}$ & 7.3 & 5.5 & 5.2 & 5.6 & 5.5 & 5.2 & -2.1 \\
\hline $\begin{array}{l}\text { North Caucasus } \\
\text { Federal District }\end{array}$ & 16.5 & 13.0 & 11.2 & 11.1 & 11.0 & 11.0 & -5.5 \\
\hline Dagestan & 14.8 & 11.6 & 10.2 & 10.8 & 10.9 & 12.0 & -2.8 \\
\hline Ingushetia & 49.7 & 43.7 & 29.8 & 30.5 & 30.2 & 27.0 & -22.7 \\
\hline $\begin{array}{l}\text { Kabardino- } \\
\text { Balkaria }\end{array}$ & 12.7 & 10.5 & 9.5 & 10.1 & 10.3 & 10.5 & -2.2 \\
\hline $\begin{array}{l}\text { Karachay- } \\
\text { Cherkessia }\end{array}$ & 10.3 & 9.8 & 13.0 & 15.1 & 14.4 & 13.5 & 3.2 \\
\hline $\begin{array}{l}\text { North Ossetia } \\
\text { Alania }\end{array}$ & 9.7 & 8.1 & 8.6 & 9.3 & 9.9 & 11.8 & 2.1 \\
\hline Chechnya & 43.3 & 26.9 & 21.5 & 17.1 & 15.8 & 14.0 & -29.3 \\
\hline Stavropol region & 6.9 & 5.6 & 5.3 & 5.6 & 5.7 & 5.2 & -1.7 \\
\hline
\end{tabular}

The highest unemployment rate in the entities of the NCFD in 2018 is observed in Ingushetia (27\%) despite a significant decrease in its value ( -22.7 percentage points) compared to 2010. The lowest unemployment rate in the NCFD corresponding to the average Russian value (5.2\%) is observed in the Stavropol Territory. The proportion of unemployed men is higher than the share of unemployed women both in the RF and in the NCFD due to its prevalence in the KBR, KChR, Chechnya and the Stavropol Territory. It is also observed that the share of rural unemployed is greater than the proportion of the urban part of the population who do not have a place to receive income (Table 03).

TABLE III. DYNAMICS OF THE NUMBER OF UNEMPLOYED AND ITS COMPOSITION IN THE SUBJECTS OF THE NORTH CAUCASUS FEDERAL DISTRICT

\begin{tabular}{|c|c|c|c|c|c|c|c|}
\hline \multirow{4}{*}{ Region } & 2010 & 2014 & 2018 & \multicolumn{4}{|c|}{2018 year } \\
\hline & \multirow{3}{*}{\multicolumn{3}{|c|}{$\begin{array}{c}\text { The number of } \\
\text { unemployed, thousand } \\
\text { people }\end{array}$}} & \multicolumn{4}{|c|}{ Composition (\%) } \\
\hline & & & & \multicolumn{2}{|c|}{ by gender } & \multicolumn{2}{|c|}{$\begin{array}{l}\text { by type of } \\
\text { settlement }\end{array}$} \\
\hline & & & & men & women & urban & rural \\
\hline Russian Federation & 6373 & 4137 & 3967 & 53.0 & 47.0 & 64.0 & 36.0 \\
\hline $\begin{array}{l}\text { North Caucasus } \\
\text { Federal District }\end{array}$ & 723 & 586 & 501 & 51.1 & 48.9 & 42.4 & 57.6 \\
\hline Dagestan & 168 & 153 & 163 & 48.2 & 51.8 & 39.9 & 60.1 \\
\hline Ingushetia & 121 & 88 & 68 & 41.3 & 58.7 & 36.4 & 63.6 \\
\hline Kabardino-Balkaria & 59 & 44 & 45 & 51.1 & 48.9 & 48.2 & 51.8 \\
\hline Karachay-Cherkessia & 26 & 22 & 28 & 54.9 & 45.1 & 34.7 & 65.3 \\
\hline North Ossetia Alania & 39 & 28 & 39 & 46.5 & 53.5 & 51.2 & 48.8 \\
\hline Chechnya & 192 & 175 & 87 & 64.3 & 35.7 & 47.4 & 52.6 \\
\hline Stavropol region & 117 & 77 & 70 & 52.0 & 48.0 & 42.3 & 57.7 \\
\hline
\end{tabular}

The bulk of the unemployed are young people aged 20 to 29, so in 2018 in the RF it was $34.4 \%$, in the NCFD - $41.8 \%$, in Ingushetia $-54.3 \%$, in the $\mathrm{KChR}-30.9 \%$. The average age of an unemployed Russian person is 36.3 years; an unemployed resident of the North Caucasus Federal District is
33.4 years old. Unemployment in the entities of NCFD, therefore, has a youth character.

An analysis of the level of employment of the population revealed that in 2018 in the NCFD there was an increase of 1 percentage point (in the Russian Federation - by 0.7 percentage points) despite a decrease in the number of working population in Dagestan by 0.4 percentage points, in the KChR - by 4.8 percentage points and in North Ossetia-Al - by 2.6 pp (fig. 05).

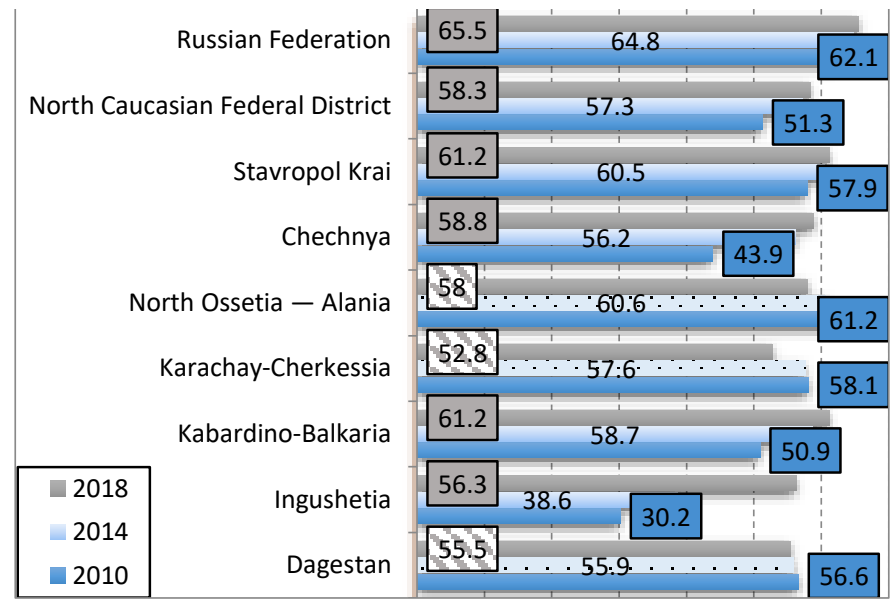

Fig. 5. Dynamics of employment in the North Caucasus Federal District, \%

Comparisons of the unemployment rate and employment of entities of the NCFD with the indicators of the RF clearly illustrate that in the regions of the NCFD the level of employment in 2010-2018 is lower than the average for the $\mathrm{RF}$ and the unemployment rate is higher than the average for the RF by more than two times.

The state providing the population with jobs is striving for its strategic goal - providing society with a decent and prosperous life, creating the necessary conditions to improve the living standards of the population [3]. The standard of living of the population is determined by the degree of provision with material goods and services and their satisfaction of their rational needs. One of the indicators for determining the standard of living of the population is the average monthly cash income per capita, which in 2018 in the NCFD amounted to 24 thousand rubles, which is a significantly low indicator compared to the average Russian per capita income.

Despite the rapid growth rate of the average monthly cash income of the population of the subjects of the NCFD from 2010 to 2018 , which exceeds the average growth rate in the $\mathrm{RF}$, the share of cash incomes of the population of the NCFD is $76.4 \%$ in the same indicator in the RF (Table 04).

In terms of average monthly income per capita in 20102018 none of the entities of the NCFD reaches the average indicators for the RF due to the fact that the income up to 7 thousand rubles has $10.5 \%$ of the population of the NCFD per month (in the $\mathrm{KChR}-14 \%$, in Ingushetia - $19.6 \%$ ), incomes from 7 to 10 thousand rubles. $12.6 \%$ of the population of the NCFD receives $16.1 \%$ in the KChR, $18.3 \%$ in Ingushetia. In the RF the proportion of the population 
earning up to 7 thousand rubles and from 7 thousand rubles up to 10 thousand rubles is half as much as in the NCFD.

TABLE IV. DYNAMICS OF THE AVERAGE MONTHLY CASH INCOME PER CAPITA IN THE SUBJECTS OF THE NORTH CAUCASUS FEDERAL DISTRICT, RUBLES

\begin{tabular}{|c|c|c|c|c|c|}
\hline \multirow[b]{2}{*}{ Region } & \multicolumn{3}{|c|}{ Years } & \multicolumn{2}{|c|}{ Changes, \% } \\
\hline & $\begin{array}{l}2010 \\
\text { year }\end{array}$ & $\begin{array}{l}2014 \\
\text { year }\end{array}$ & $\begin{array}{l}2018 \\
\text { year }\end{array}$ & $\begin{array}{c}2014 \\
\text { to } \\
2010\end{array}$ & $\begin{array}{c}2018 \\
\text { to } \\
2014\end{array}$ \\
\hline Russian Federation & 16895 & 25928 & 31422 & 153.5 & 121.2 \\
\hline $\begin{array}{l}\text { North Caucasus Federal } \\
\text { District }\end{array}$ & 11402 & 18900 & 24017 & 165.8 & 127.1 \\
\hline Dagestan & 13250 & 21717 & 29206 & 163.9 & 134.5 \\
\hline Stavropol region & 11244 & 19768 & 23403 & 175.8 & 118.4 \\
\hline North Ossetia Alania & 9978 & 17788 & 22773 & 178.3 & 128.0 \\
\hline Chechnya & 9903 & 17188 & 22202 & 173.6 & 129.2 \\
\hline Kabardino-Balkaria & 9986 & 15297 & 20385 & 153.2 & 133.3 \\
\hline Karachay-Cherkessia & 9201 & 14664 & 17142 & 159.4 & 116.9 \\
\hline Ingushetia & 8000 & 13821 & 15131 & 172.8 & 109.5 \\
\hline
\end{tabular}

As a result of calculating the specific gravity of the average monthly monetary income per capita of the entities of the NCFD in average Russian indicators, it was found that they are significantly lower than the latter, moreover, in Ingushetia and the KChR their values are half as low (Table 05)

TABLE V. DYNAMICS OF THE INDICATOR OF THE RATIO OF THE AVERAGE MONTHLY MONETARY INCOME PER CAPITA OF THE SUBJECTS OF THE NORTH CAUCASUS FEDERAL DISTRICT TO THE SIMILAR AVERAGE RUSSIAN INDICATOR, \%

\begin{tabular}{|l|l|l|l|}
\hline \multicolumn{1}{|c|}{ Region } & \multicolumn{1}{c|}{$\mathbf{2 0 1 0}$ year } & \multicolumn{1}{c|}{$\mathbf{2 0 1 4}$ year } & 2018 year \\
\hline Russian Federation & 100.0 & 100.0 & 100.0 \\
\hline North Caucasus Federal District & 67.5 & 72.9 & 76.4 \\
\hline Dagestan & 78.4 & 83.8 & 92.9 \\
\hline Stavropol region & 66.6 & 76.2 & 74.5 \\
\hline North Ossetia Alania & 59.1 & 68.6 & 72.5 \\
\hline Chechnya & 58.6 & 66.3 & 70.7 \\
\hline Kabardino-Balkaria & 59.1 & 59.0 & 64.9 \\
\hline Karachay-Cherkessia & 54.5 & 56.6 & 54.6 \\
\hline Ingushetia & 47.4 & 53.3 & 48.2 \\
\hline
\end{tabular}

An extremely unfavorable situation has developed in Ingushetia: $38 \%$ of the population have incomes of up to 10 thousand rubles, $58.2 \%$ receive incomes of up to 14 thousand rubles. A tense situation has developed in KarachayevoCherkessia: a third of the population receives incomes up to 10 thousand rubles, more than half of the population receives incomes only up to 14 thousand rubles. Dagestan is closest to the average Russian indicators in terms of cash income, in which $25.2 \%$ of the population receives incomes up to 14 thousand rubles; the remaining $75 \%$ receive more worthy incomes (Table 06).

Despite a significant share of the population of the NCFD with incomes below the minimum incomes we note that in 2018 there was a more favorable situation than four years ago.

The growth rate of the population with incomes below the subsistence level in the entities of the NCFD in the period from 2010 to 2018 is positive. The worst situation is in Ingushetia, where a third of the population receives income below the subsistence level. In the KChR and the KBR a quarter of the population also has income below the subsistence level which is an absolutely negative fact of the quality of living of population (fig. 06).

TABLE VI. PERCENTAGE OF THE POPULATION OF THE SUBJECTS OF THE NORTH CAUCASIAN FEDERAL DISTRICT IN TERMS OF AVERAGE MONTHLY INCOME IN 2018, \%

\begin{tabular}{|c|c|c|c|c|c|c|c|c|}
\hline \multirow[b]{2}{*}{ Region } & \multicolumn{8}{|c|}{ Monthly income } \\
\hline & 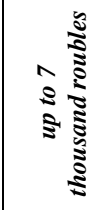 & 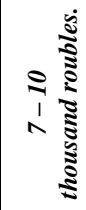 & 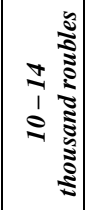 & 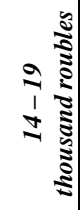 & 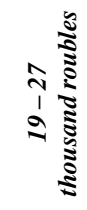 & 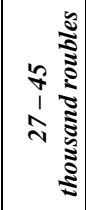 & 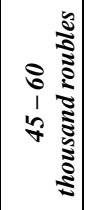 & 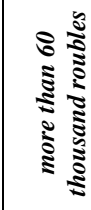 \\
\hline $\begin{array}{l}\text { Russian } \\
\text { Federation }\end{array}$ & 5.5 & 7.4 & 11.7 & 14.2 & 18.3 & 23.2 & 8.8 & 10.9 \\
\hline $\begin{array}{l}\text { North Caucasus } \\
\text { Federal District }\end{array}$ & 10.5 & 12.6 & 17.0 & 17.3 & 18.0 & 16.6 & 4.5 & 3.5 \\
\hline Dagestan & 5.1 & 7.7 & 12.4 & 15.2 & 19.4 & 23.4 & 8.2 & 8.6 \\
\hline $\begin{array}{l}\text { Stavropol } \\
\text { region }\end{array}$ & 8.5 & 10.9 & 15.7 & 17 & 18.9 & 19 & 5.5 & 4.5 \\
\hline $\begin{array}{l}\text { North Ossetia } \\
\text { Alania }\end{array}$ & 7.4 & 10.8 & 16.2 & 17.9 & 19.8 & 19.1 & 5.1 & 3.7 \\
\hline Chechnya & 9.9 & 11.8 & 16.3 & 17.1 & 18.4 & 17.7 & 4.9 & 3.9 \\
\hline $\begin{array}{l}\text { Kabardino- } \\
\text { Balkaria }\end{array}$ & 8.8 & 12.6 & 18.1 & 18.9 & 19.3 & 16.4 & 3.7 & 2.2 \\
\hline $\begin{array}{l}\text { Karachay- } \\
\text { Cherkessia }\end{array}$ & 14 & 16.1 & 20.1 & 18.3 & 16.4 & 11.8 & 2.2 & 1.1 \\
\hline Ingushetia & 19.6 & 18.3 & 20.3 & 16.8 & 13.8 & 8.9 & 1.6 & 0.7 \\
\hline
\end{tabular}

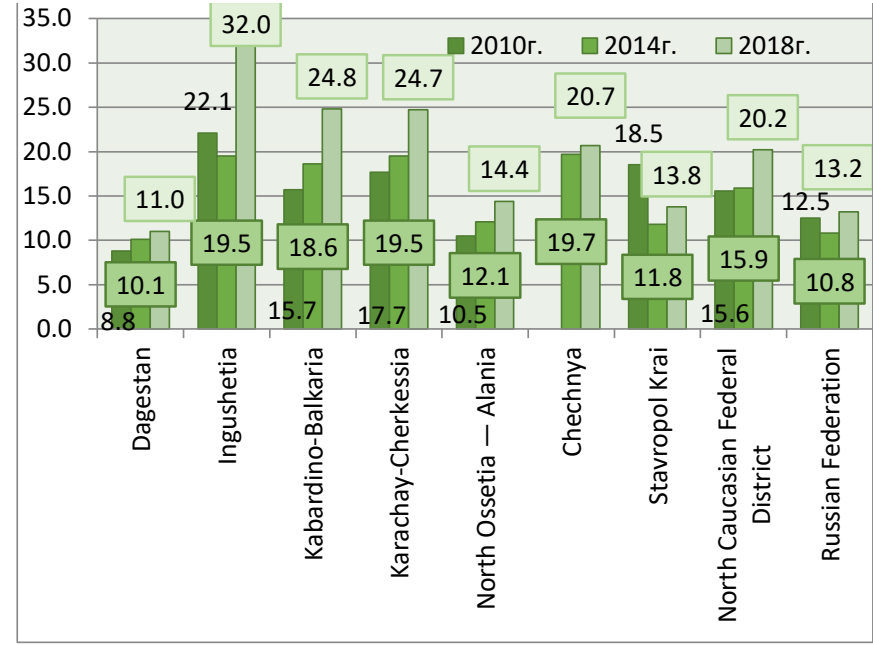

Fig. 6. Dynamics of the population with incomes below the subsistence level of the subjects of the North Caucasus Federal District, \%

An analysis of the dynamics of the population with incomes in money terms below the subsistence minimum in the entities of the NCFD in 2010-2018 revealed that one fifth of the population of the NCFD was below the poverty line in 2018 (in 2010 it was $16 \%$ ), $13.2 \%$ of the RF population (in $2010-12.5 \%)$.

\section{CONCLUSION}

An overview of the social-economic development of the constituent territories of the North Caucasus Federal District made it possible to establish positive dynamics in the population, life expectancy, and mortality rate. An analysis of 
the population employed in agriculture in the NCFD showed a negative trend.

Despite the growth trends of certain indicators, in general, the region is characterized by high migration of the population to the regions of the RF, high unemployment, low employment and the salary value of employees of organizations; low per capita cash income, consumer spending per capita; budgetary security, subsidization (that is, the entities of the NCFD are characterized by the properties of recipients, among which Ingushetia and the $\mathrm{KChR}$ are especially distinguished, receiving from the federal budget more than $90 \%$ and more than $70 \%$ of the financial resources of the entity, respectively; however, these funds are mainly not used to stimulate and develop real sectors of the economy but to maintain the social development of the population) [4].

The key direction of the region's economic growth should be the strategic development of agriculture in the constituent territories of the NCFD, the creation of jobs and raising the standard of living of the population. In addition, the studied constituent territories have sufficient natural resources (about $30 \%$ of all mineral waters of the RF), an excess of ablebodied population with a significant share of the rural population, favorable and even unique climatic conditions for the development of spa, recreation, tourism and recreation, mountaineering, mining and manufacturing industries (deposits of about $41 \%$ of tungsten, $11 \%$ of molybdenum, $4.8 \%$ of oil, $2.1 \%$ of gas from the total reserves of the Russian Federation).

The results of the research can be used in programs in identifying systemic problems and working out the development of innovative and investment activities of the regional economy; while ensuring coordinated policy of the region and working a forecast for the development of the main branches of the regional economy; while improving regulatory and organizational support and improving mechanisms of state support.

\section{References}

[1] N.A. Azarova, A.Y. Nebesnaya, A.S. Sviridov, L.E. Glagoleva, "Analysis of human capital in the region as a source of import substitution", Proc. of Voronezh State Univer. of Engineer. Technol., vol. 80, no. 3, pp. 451-457, 2018, Retrieved from: https://doi.org/10.20914/2310-1202-2018-3-451-457

[2] V.M. Bautin, I.S. Dzahmisheva, A.A. Akbasheva, "The main directions of increase of efficiency of use of land resources in the KarachayCherkess republic", Proc. of Voronezh State Univer. of Engineer. Technol., vol. 80, no. 3, pp. 377-381, 2018, Retrieved from: https://doi.org/10.20914/2310-1202-2018-3-377-381

[3] V.A. Bogutskiy, A.G. Volkova, "Formation and use of human potential of rural areas", Proc. of Voronezh State Univer. of Engineer. Technol., vol. 80, no. 3, pp. 471-477, 2018, Retrieved from: https://doi.org/10.20914/2310-1202-2018-3-471-477
[4] I.I. Galimova, O.M. Pasynkova, L.N. Chaikovskaya, "Assessment of investment attractiveness of Voronezh region", Proc. of Voronezh State Univer. of Engineer. Technol., vol. 81, no. 2, pp. 285-289, 2019, Retrieved from: https://doi.org/10.20914/2310-1202-2019-2-285-289

[5] A.N. Desyatirikov, Y.B. Nechaev, E.N. Desyatirikova, E.A. Lyutova, "The mechanism of attracting investment in the regional economy on the example of Voronezh region", Proc. of the Voronezh State Univer. of Engineer. Technol., vol. 80, no. 4, pp. 378-383, 2018, Retrieved from: https://doi.org/10.20914/2310-1202-2018-4-378-383

[6] Y.V. Zhuravlev, I.V. Kuksova, E.A. Gubertov, L.I. Churikov, "Evaluation of innovative development of the Russian Federation based on the 2020 vision and strategy indicators", Proc. of Voronezh State Univer. of Engineer. Technol., vol. 81, no. 2, pp. 377-382, 2019, Retrieved from: https://doi.org/10.20914/2310-1202-2019-2-377-382

[7] I.A. Kiseleva, N.E. Simonovich, E.D. Solomatina, "Social well-being of people and the strategy of innovative development of the enterprise", Proc. of Voronezh State Univer. of Engineer. Technol., vol. 81, no. 1, pp. 402-411, 2019, Retrieved from: https://doi.org/10.20914/2310-12022019-1-402-411

[8] V.A. Kozlov, O.A. Frolova, Y.A. Yukhlina, "Development of recommendations to provide grants for beginning farmers", Proc. of Voronezh State Univer. of Engineer. Technol., vol. 81, no. 1, pp. 329-336, 2019, Retrieved from: https://doi.org/10.20914/2310-1202-2019-1-329336

[9] M.V. Ledeneva, T.A. Plaksunova, "Creating an innovation ecosystem in the regions of the Russian Federation (by the example of the Volgograd region)", Proc. of Voronezh State Univer. of Engineer. Technol., vol. 80, no. 4, pp. 484-492, 2018, Retrieved from: https://doi.org/10.20914/2310-1202-2018-4-484-492

[10] G.S. Merzlikina, "Economic efficiency of "ecological health" of the region", Proc. of Voronezh State Univer. of Engineer. Technol., vol. 81, no. 2, pp. 312-319, 2019, Retrieved from: https://doi.org/10.20914/2310-1202-2019-2-312-319

[11] T.A. Nekrasova, "The problems of optimization the quality of life in modern Russia through the prism of economic theory and practice", Proc. of Voronezh State Univer. of Engineer. Technol., vol. 80, no. 3, pp. 386-391, 2018, Retrieved from: https://doi.org/10.20914/2310-12022018-3-386-391

[12] T.I. Ovchinnikova, G.N. Strukov, "Measures to reduce unemployment", Bull. of Voronezh State Univer. of Engineer. Technol., vol. 80, no. 4, pp. 471-478, 2018, Retrieved from: https://doi.org/10.20914/2310-12022018-4-471-478 /

[13] A.A. Orekhov, D.S. Kleimenov, E.D. Kuznetsova, "SWOT-analysis as a tool for assessing the socio-economic development of municipalities", Proc. of Voronezh State Univer. of Engineer. Technol., vol. 80, no. 3, pp. 416-422, 2018, Retrieved from: https://doi.org/10.20914/2310-12022018-3-416-422

[14] N.A. Serebryakova, I.V. Avdeev, "The content of structural transformations of the region's economy, adequate to the requirements of digitalization", Proc. of Voronezh State Univer. of Engineer. Technol., vol. 80, no. 4, pp. 408-412, 2018, Retrieved from: https://doi.org/10.20914/2310-1202-2018-4-408-412

[15] Y.M. Sokolinskaya, "Model of interaction of the state and small entrepreneurship", Proc. of Voronezh State Univer. of Engineer. Technol., vol. 81, no. 1, pp. 449-456, 2019, Retrieved from: https://doi.org/10.20914/2310-1202-2019-1-449-456

[16] A.S. Chekunov, "Technological modernization of agricultural production: condition, forms, methods and directions of innovations support", Proc. of Voronezh State Univer. of Engineer. Technol., vol. 81, no. 1, pp. 373-379, 2019, Retrieved from: https://doi.org/10.20914/2310-1202-2019-1-373-379 